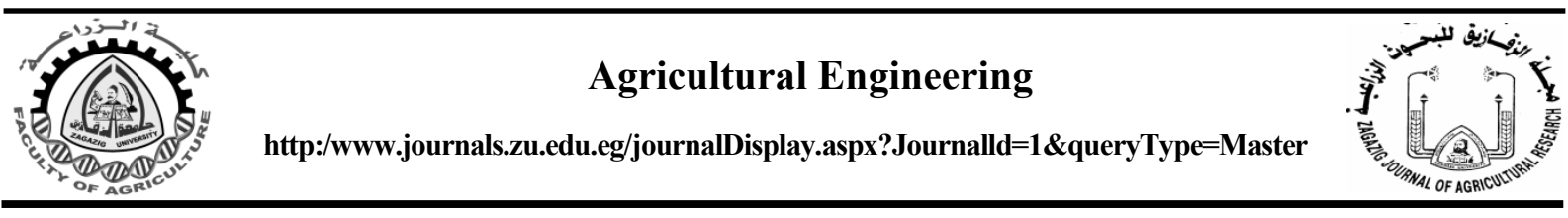

\title{
MANUFACTURE AND PERFORMANCE EVALUATION OF A LOCAL HARVESTING MACHINE FOR SILAGE PREPARATION
}

\author{
Ashraf S.E. Ali", M. El-Shazly and M.M. Morad \\ Agric. Eng. Dept., Fac. Agric., Zagazig Univ., Egypt
}

Received: 14/05/2017 ; Accepted: 19/07/2017

\begin{abstract}
The present research was carried out to manufacture and evaluate the performance of a local silage-harvesting machine to improve harvesting efficiency. The manufactured machine consists mainly of frame, hitching device, transmission system, harvesting device and power source. The manufactured machine performance was studied as a function of change in machine forward speed, knife velocity, knife inclination angle and stalk moisture content. Performance evaluation was conducted in terms of field capacity and field efficiency, harvesting losses and harvesting efficiency, required power, energy requirements and criterion cost. The experimental results revealed that harvesting losses as well as criterion costs were minimum while harvesting efficiency was maximum under the following conditions: Operate the machine at a forward speed of $2.5 \mathrm{~km} / \mathrm{hr}$. Operate the harvesting device at a knife velocity of $1250 \mathrm{rpm}$. Adjust knife inclination angle at zero degree. Harvest silage at a stalk moisture content of about $69 \%(\mathrm{wb})$.
\end{abstract}

Key words: Harvesting machine, silage production, knife velocity, energy requirements.

\section{INTRODUCTION}

Agricultural policy depends on the successful technology through mechanizing the agricultural processes. Mechanization of forage crops harvesting is considered of great importance to reduce time labor and cost. Corn is a crop that is grown widely throughout the world in a range of agro ecological environments. In Egypt corn production and planted area official estimate of 6.0 MMT (million metric tons) and 750,000 ha, respectively. White corn accounts for 550,000 ha producing 4.4 MMT, while yellow corn constitutes around 200,000 ha producing 1.6 MMT (GAIN Report, 2016).

There are many types of imported corn crop harvesting machines such as tractor mounted harvesting machines, self-propelled harvesting machines and combine harvesters. The mentioned machines are complex in construction and expensive. The major concern with the use of mowing machines for harvesting corn is to cut the crop with minimum and

\footnotetext{
* Corresponding author: Tel. : +201065102221

E-mail address: ashrafsaee@gmail.com
}

uniform stubble heights in order to increase the yield.

Such studies had to be carried out to solve the problem of corn harvesting under conditions of small Egyptian farms. Local silage-harvesting machines are the successful answer to prepare silage. Therefore, such care had to be taken to design, manufacture and develop a simple low cost machine from local material to be used for silage harvesting taking into consideration its effectiveness. Canadian Farm and Industrial Equipment (CFIEI, 2002) reported that the most common harvesting systems for whole corn silage use a precision-cut cylinder harvester. This type of machine uses a horizontal drum with several helicoidally knives. The crop is usually cut into lengths varying from 6 to 12 $\mathrm{mm}$. Forage harvesters are manufactured in two configurations: pull-type and self-propelled. Pull-type forage harvesters (PTFH) generally range in capacity from 40 to $70 \mathrm{Mg}$ (wet basis) per hour and are adapted for smaller farms. Bentini et al. (2008) compared two forage 
harvesting methods (a) whole-plant chopping and (b) field drying and baling. The cutterchopper-loader used for harvesting cut at a height of 10-20 cm, leaving considerable basal biomass unharvested. With the baler methods, the production of large round bales involved considerable yield losses during field operations so that the final biomass yield averaged 14.6 $\mathrm{Mg} / \mathrm{ha}$. Shinners et al. (2009) harvested corn stover with a modified combine that simultaneously harvested grain and stover in separate streams. The harvester was used to collect the following stover fractions using three different heads: cob and husk (ear-snapper head); stalk and leaves (stalk-gathering head); and stalks, leaves, husk, and cob (whole-plant head). Material harvested with the ear-snapper, whole-plant, or stalk-gathering head had average moisture of $38.2 \%, 45.0 \%$, and $46.7 \%$ (wb). Area productivity was $3.4,1.5$, and $1.9 \mathrm{ha} / \mathrm{hr}$; fraction of available stover dry mater (DM) actually harvested was $18 \%, 64 \%$, and $49 \%$ and total harvester specific fuel use was 1.46, 2.07 and $1.831 / \mathrm{Mg} \mathrm{DM}$ or $17.0,33.4$, and $27.41 / \mathrm{ha}$ for the ear-snapper whole-plant, and stalkgathering head configurations, respectively. Chattopadhyay et al. (1999) evaluated four types of forage harvesting machines, namely flail mower, rotary mower, rotary disk mower and mechanical rake-cum-windrower for harvesting grasses (cencrusciliaris). The average effective field capacities were found to be $0.21,0.03$ and $0.285 \mathrm{ha} / \mathrm{hr}$., for flail mower, rotary mower and rotary disk mower, respectively. Diao et al. (2011) stated that most of the current corn harvesters is to solve the problem occurred during corn and straw harvesting, which is generally used as organic fertilizer being reused in field. In order to solve the comprehensive utilization of straws and stalks of maize, a new design idea is proposed which is composed by reciprocating knife cutting straw, gripping chain conveying straw with corn, vertical harvest, plate cutter chopping straw, throwing device transmitting the chopped corn stalk. The design was applied in self-propelled type of corn combine harvester for corn and stalk.

Many factors control the performance of silage-harvesting machine. These factors can be divided into two sections: machine and material.
Machine variables include machine forward speed, knife velocity and knife inclination angle. Moreover, material variables such as stalk moisture content and degree of crop maturity are considered critical factors. The mentioned factors affect directly on the harvesting losses, energy requirements, efficiency, productivity, and the operational cost.

It is obvious from the above literature review that several investigations are needed to predict the performance of silage-harvesting machine to optimize the operational factors.

The objectives of the present study are as follow:

- Manufacture a local silage-harvesting machine from low cost and local materials.

- Select some different operating parameters affecting the performance of the manufactured machine.

- Evaluate the manufactured silage-harvesting machine from the economic point of view.

\section{MATERIALS AND METHODS}

Experiments were carried out through two years of 2015 and 2016 in El-Taleen village, Minya El-Kameh district, Sharkia Governorate, Egypt to manufacture and evaluate the performance of local machine suitable for harvesting corn crop for silage production.

\section{Materials}

\section{The harvested crop}

The corn plant (Giza 125) is often $2.5 \mathrm{~m}$ height. The stem has the appearance of a bamboo cane and is commonly composed of 20 internodes of $18 \mathrm{~cm}$ length.

\section{The manufactured silage-harvesting machine}

A local machine, suitable for silage harvesting, was manufactured from low cost, local materials to overcome the problems of high power and high cost requirements under the use of the imported machine.

The harvesting machine was manufactured specially for this work and constructed at a small workshop in El-Taleen village, Minya ElKameh District, Sharkia Governorate. 
The local manufactured machine must meet several requirements:

- The local machine must be manufactured to effectively harvest a range of different green crops.

- The manufactured machine must be able to do above tasks while avoiding over crop losses.

- The manufactured machine must be reliable and provide gentle handling of the tasks during the harvesting operation.

- It is very important to control cutting speed to cut uniformly through the field.

The manufactured machine, which consists mainly of frame, hitching device, transmission system, harvesting device and power source, is shown in Figs. 1 and 2.

The machine frame is made of local steel 48 ([) section of $4 \mathrm{~mm}$ thickness. Two steel 37 carriers (rectangular section area) were connected with the frame by six screw bolts (for each) to carry the entire harvesting device parts. The horizontal distance between the centers of the two carriers is adjusted at $620 \mathrm{~mm}$. Each carrier length is 675 $\mathrm{mm}$, while its rectangular cross sectional area is $100 \mathrm{~mm}$ width and $18 \mathrm{~mm}$ thickness.

\section{The harvesting device}

The harvesting device consists mainly of two units. Each unit containing hydraulic motor (OMP50), main shaft, harvesting device shaft, unit for cutting plants by rotary saw (knife drum) and shifting unit for shifting plants by rotary drivers.

The main shaft is operated directly by the hydraulic motor. The main shaft is supported by two bearings. V- belt is fixed on a pulley ( 350 $\mathrm{mm}$ diameter) in the end of the main shaft to transport motion to another pulley $(70 \mathrm{~mm}$ diameter), which is fixed on the harvesting device shaft to power the knife drum. An endless chain is engaged with the teeth of sprocket (12 teeth) in the other end of the main shaft to transport motion to another sprocket (65 teeth), which is fixed on the harvesting device to power the rotary fingers drivers. The cutting units cut the plant depending on impact cutting.

The cutting unit consists of two circular saws (knife drum) of opposite direction of rotation.
The total knife drum mass is $(15 \mathrm{~kg})$ and $(600$ $\mathrm{mm}$ diameter) made from two parts, the first part was maded from steel of $10 \mathrm{~mm}$ thickness , 500 $\mathrm{mm}$ diameter and $13 \mathrm{~kg}$ mass. The second part is the knife blades with $2 \mathrm{~mm}$ thickness, $100 \mathrm{~mm}$ width and $2 \mathrm{~kg}$ mass. The knife drum rotates at high rotational speed of $1400 \mathrm{rpm}(43.96 \mathrm{~m} / \mathrm{sec}$.) to achieve very clean cutting of forage plant.

The shifting unit consists of two rotary finger drivers. The rotary finger drivers shift plants with simultaneous directing of plants towards the throat. The rotary finger drivers are made of steel of $3 \mathrm{~mm}$ thickness and $500 \mathrm{~mm}$ diameter.

\section{The transmission system}

Motion is transmitted from the hydraulic motor to main shaft, then through pulleys and belts to the cutting unit through sprockets and chain to the shifting unit.

\section{The power source}

A Belarus tractor model D-243.1with 4 cylinders diesel engine-59 kW (80 hp) was used as a power source.

The harvesting machine was mounted on the tractor while its hydraulic pump was used to power the harvesting device hydraulic motors.

The overall dimensions of the manufactured machine were as follows:

Overall length $1097 \mathrm{~mm}$, overall width 1218 $\mathrm{mm}$, overall height $1092 \mathrm{~mm}$ and total mass 350 $\mathrm{kg}$.

\section{Methods}

Experiments were carried out to evaluate the performance of the local manufactured silageharvesting machine to optimize the values of the main operating parameters during the harvesting operation.

\section{Experimental conditions}

The performance of the manufactured machine was experimentally measured under the following parameters:

- Four different tractor forward speeds $(1.1,1.8$, 2.5 and $3.6 \mathrm{~km} / \mathrm{hr}$ ).

- Four different knife velocities (950, 1050, 1250 and $1350 \mathrm{rpm}$ ) corresponding to (18.84, $32.97,39.25$ and $42.39 \mathrm{~m} / \mathrm{sec}$.) respectively. 


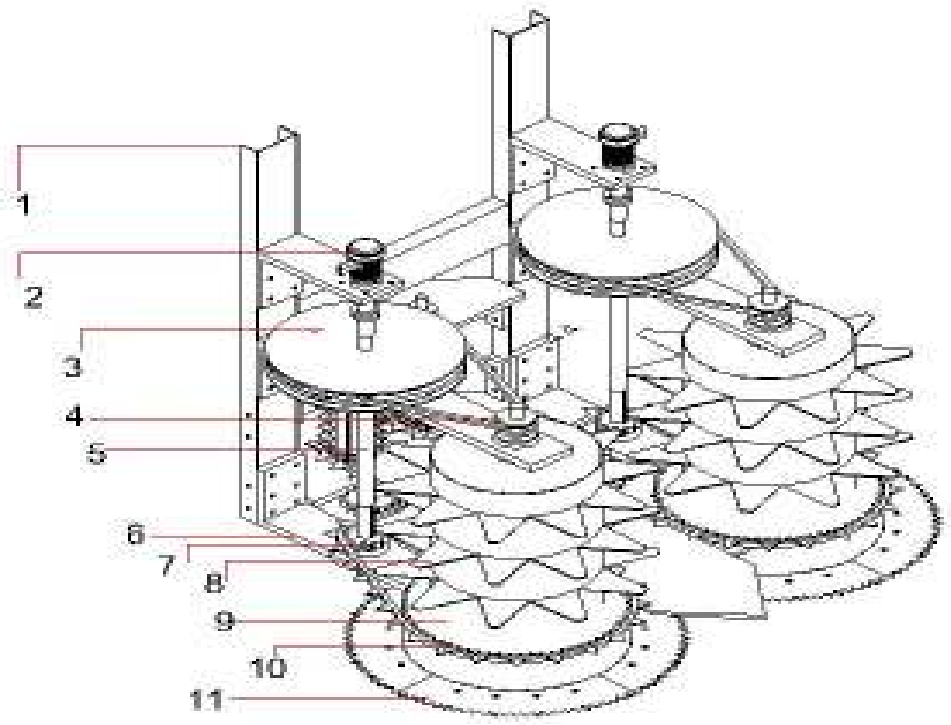

\begin{tabular}{|c|l|}
\hline No. & Part name \\
\hline 1 & Main frame \\
\hline 2 & Hydraulic motor \\
\hline 3 & Large pulley Q35 \\
\hline 4 & Small pulley Q7 \\
\hline 5 & Main shaft \\
\hline 6 & Down carrier \\
\hline 7 & Sprocket 12 teeth \\
\hline 8 & Handing device \\
\hline 9 & Sprocket 65 teeth \\
\hline 10 & Chain \\
\hline 11 & Cutting knife \\
\hline
\end{tabular}

Fig. 1. Isometric of the manufactured silage-harvesting machine

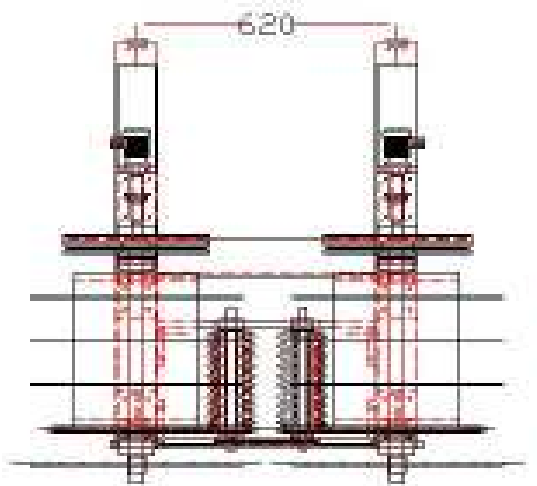

Elevation

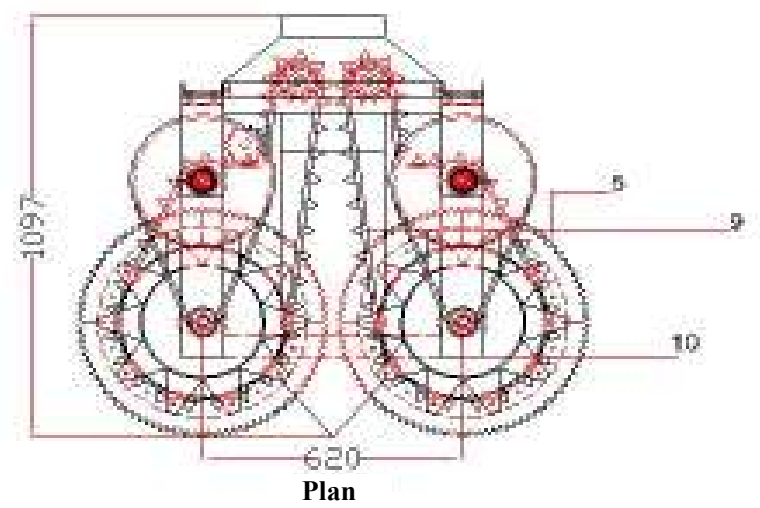

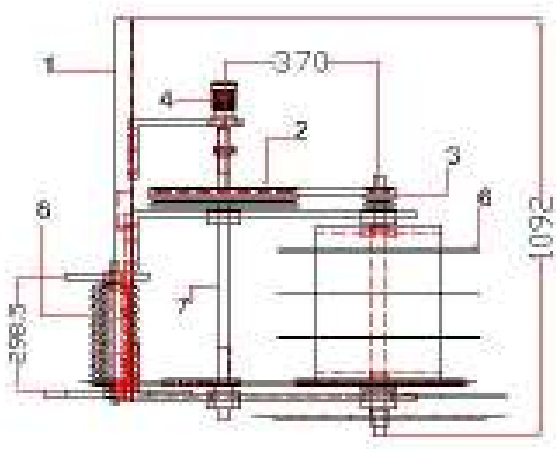

Side view

All dimensions in, $\mathrm{mm}$

\begin{tabular}{|c|l|c|l|c|l|}
\hline No. & Part name & No. & Part name & No. & Part name \\
\hline 1 & Main frame & 5 & Knife & 9 & Chain \\
\hline 2 & Large pulley & 6 & $\begin{array}{l}\text { Handling } \\
\text { device }\end{array}$ & 10 & $\begin{array}{l}\text { Upper } \\
\text { carrier }\end{array}$ \\
\hline 3 & Small pulley & 7 & Main shaft & & \\
\hline 4 & Hydraulic motor & 8 & Out put rollers & & \\
\hline
\end{tabular}

Fig. 2. Elevation, side view and plan of the manufactured silage-harvesting machine 
- Two different knife inclination angles $\left(0^{0}\right.$ and $30^{\circ}$ ).

- Two different stalk moisture contents (69 and $61 \%$ w.b).

\section{Measurements and determinations}

Performance evaluation of the manufactured machine was conducted as follows:

\section{Actual field capacity}

Actual field capacity is the actual average rate of coverage by the machine, based upon the total effective operating time. It was function of the rate width of the machine (Kepner et al., 1987). Thus, it can be calculated as follows:

Where:

$$
\text { F. } \mathrm{C}_{\mathrm{act}}=\frac{1}{\mathrm{~T}_{\mathrm{t}}}
$$

F. $\mathrm{C}_{\mathrm{act}}$ - Actual field capacity. (fad/hr)

$\mathrm{T}_{\mathrm{t}}$ - Total effective operating time. (hr./fad)

\section{Field efficiency}

Field efficiency can be calculated by using the values of theoretical field capacity and effective field capacity rates as:

$$
\eta_{\mathrm{f}}=\frac{\mathrm{F} \cdot \mathrm{C}_{\mathrm{act}}}{\mathrm{F} \cdot \mathrm{C}_{\mathrm{th}}} 100
$$

Where:

$\eta_{\mathrm{f}} \quad$ - Field efficiency (\%)

F. $C_{\text {act }}$ - Actual field capacity (fad./hr.)

F. $C_{\text {th }}$ - Theoretical field capacity (fad./hr.)

\section{Harvesting losses and harvesting efficiency}

After the harvesting operation, under all treatments, the remainder corn crop stubble height was recorded and converted into mass to determine harvesting losses.

The harvesting efficiency was estimated as a percentage by using the following equation:

$$
\eta_{\mathrm{f}}=\frac{\mathrm{W}_{\mathrm{a}}-\mathrm{W}_{\mathrm{b}}}{\mathrm{W}_{\mathrm{a}}} \times 100
$$

Where:

$\eta_{\mathrm{f}}$ - Harvesting efficiency (\%)
$\mathrm{W}_{\mathrm{a}}$ - Mass of corn crop above the soil before the harvesting operation $\left(\mathrm{kg} / \mathrm{m}^{2}\right)$

$\mathrm{W}_{\mathrm{b}}$ - Mass of corn crop above the soil after the harvesting operation $\left(\mathrm{kg} / \mathrm{m}^{2}\right)$

\section{Fuel consumption}

Fuel consumption per unit time was determined by using a calibrated tank (Refilling method) to measure the volume of fuel consumed during the operation time. It can be calculated by the following equation:

$$
\mathrm{F}_{\mathrm{c}}=\frac{\mathrm{V}_{\mathrm{f}}}{\mathrm{T}} \times 3.5
$$

Where:

$F_{c}$ - Fuel consumption rate $(1 / h r)$.

$\mathrm{V}_{\mathrm{f}}$-Volume of fuel consumption $\left(\mathrm{cm}^{3}\right)$

$\mathrm{T}$ - Time of operation (sec.)

\section{- Required power}

The required power was calculated by using the following formula (Hunt, 1983).

$\mathrm{P}=\left[\mathrm{F}_{\mathrm{c}}\left(\frac{1}{3600}\right) \rho_{\mathrm{E}} \times\right.$ L.C.V. $\left.\times \eta_{\mathrm{th}} \times \eta_{\mathrm{m}} \times \frac{427}{75 \times 1.36}\right]$

Where:

$\mathrm{p}$ - Required power, $\mathrm{kW}$

$F_{c}$ - Fuel consumption, 1/hr.,

$\rho_{\mathrm{E}^{-}}$fuel density, for gas oil 0.85

L.C.V. - Calorific value of fuel, kcal (Average

L.C.V. of solar fuel is $11000 \mathrm{kcal} / \mathrm{kg}$ )

427-Thermo-mechanical equivalent, kg.m/kcal

$\eta_{\text {th}^{-}}$Thermal efficiency of the engine, (Considered to about 35\% for diesel engine)

$\eta_{\mathrm{m}}$ - Mechanical efficiency of the engine, (Considered to be about $83 \%$ for diesel engine)

$$
\mathrm{P}=3.16 \mathrm{~F}_{\mathrm{c}}
$$

\section{Energy requirement}

Energy requirement was estimated according to the following equation: 


$$
\mathrm{E}=\frac{\mathrm{P}}{\mathrm{F} \cdot \mathrm{C}_{\mathrm{act}}}
$$

Where:

E-Energy requirement (kW. hr/fad.).

$\mathrm{p}$ - Required power $(\mathrm{kW})$.

$\mathrm{FC}_{\text {act }}$ - Actual field capacity (fad./hr.).

\section{The criterion cost}

The cost of harvesting operation was based on the initial cost of machine, interest on capital, cost of fuel, oil consumed, cost of maintenance and wage of the operator. The hourly cost was estimated according to the conventional method of estimating both fixed and variable costs.

The operational cost can be determined by using the following formula:

Operational cost $(\mathrm{LE} / \mathrm{fad})=$.

Machine hourly cost (LE/hr.)

Actual field capacity (fad./hr.)

The cost per unit of production can be determined by using the following formula:

Cost per unit of production $(\mathrm{LE} / \mathrm{Mg})=$

Operational cost (LE/fad.)

Productivity (Mg/fad.)

The criterion cost can be determined by using the following formula:

Criterion cost $(\mathrm{LE} / \mathrm{Mg})=$ Cost per unit of production (LE/Mg)+Crop losses cost (LE/ Mg).

\section{RESULTS AND DISCUSSION}

Discussion will cover the results obtained using silage-harvesting machine under the following heading:

\section{Effect of Some Operating Parameters on Field Capacity and Field Efficiency}

The effects of forward speed as well as knife inclination angle and silage moisture content on field capacity and field efficiency of silage harvesting machine are shown in Fig. 3. The obtained results show a remarkable drop in field efficiency with a consequent sharp rise in actual field capacity as the forward speed increased.
Results show that increasing forward speed from 1.1 to $3.6 \mathrm{~km} / \mathrm{hr}$., at $0^{0} \mathrm{knife}$ inclination angle, increased actual field capacity values from 0.31 to 0.93 and from 0.36 to 1.1 fad. $/ \mathrm{hr}$., under corn moisture contents of 61 and $69 \%$, respectively. While increasing forward speed from 1.1 to $3.6 \mathrm{~km} / \mathrm{hr}$, at $30^{\circ} \mathrm{knife}$ inclination angle, increased actual field capacity values from 0.3 to 0.9 and from 0.33 to 0.97 fad./hr., under the same previous conditions.

On the other hand, increasing forward speed from 1.1 to $3.6 \mathrm{~km} / \mathrm{hr}$, at $0^{0} \mathrm{knife}$ inclination angle, leads to decrease field efficiency values from 73.8 to 66.4 and from 85.7 to $78.6 \%$ under corn moisture contents of 61 and $69 \%$, respectively. While increasing forward speed from 1.1 to $3.6 \mathrm{~km} / \mathrm{hr}$., at $30^{\circ} \mathrm{knife}$ inclination angle, leads to decrease field efficiency values from 71.4 to 64.3 and from 78.5 to $69.3 \%$ under the same previous conditions. From this point of view, it was noticed that the highest field capacity of $1.1 \mathrm{fad} . / \mathrm{hr}$., was obtained at forward speed of $3.6 \mathrm{~km} / \mathrm{hr}$, $0^{0}$ knife inclination angle and corn moisture content of $69 \%$. Meanwhile the lowest field capacity of $0.3 \mathrm{fad} . / \mathrm{hr}$., was obtained at forward speed of $1.1 \mathrm{~km} / \mathrm{hr}$., $30^{\circ}$ knife inclination angle and silage moisture content of $61 \%$. At the same time, the highest value of field efficiency of $85.7 \%$ was noticed at forward speed of $1.1 \mathrm{~km} / \mathrm{hr}, 0^{0}$ knife inclination angle and silage moisture content of $69 \%$. Meanwhile the lowest value of field efficiency of $64.3 \%$ was obtained at forward speed of 3.6 $\mathrm{km} / \mathrm{hr}, 30^{\circ} \mathrm{knife}$ inclination angle and corn moisture content of $61 \%$.

The major reason for the reduction in field efficiency by increasing forward speed is due to the less theoretical time consumed in comparison with the other items of time losses.

\section{Effect of Some Operating Parameters on Machine Productivity}

Forward speed, knife inclination angle and silage moisture content affects the machine productively (Fig. 4). The obtained results show a consequent sharp rise in machine productivity as the forward speed increased.

Results showed that increasing forward speed from 1.1 to $3.6 \mathrm{Km} / \mathrm{hr}$, at $0^{0} \mathrm{knife}$ inclination angle, increased machine productivity values from 


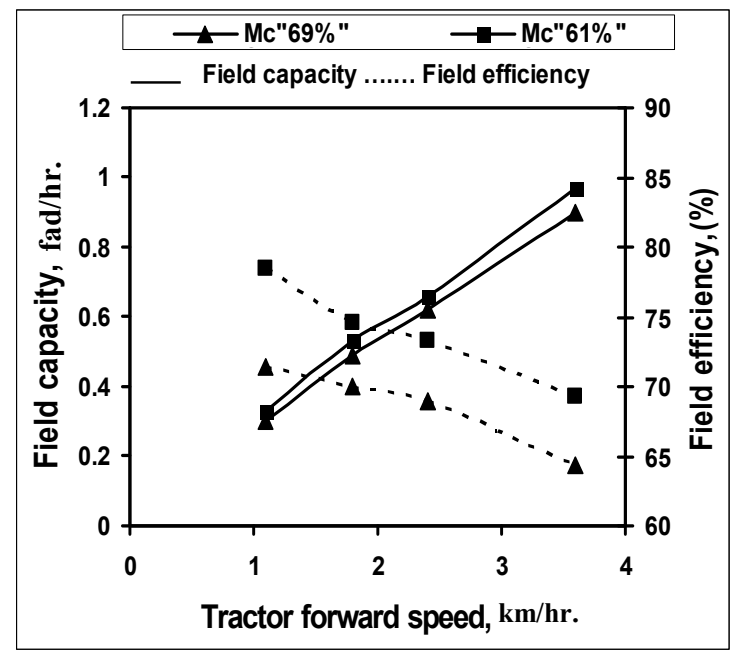

Knife inclination angle $\left(30^{\circ}\right)$

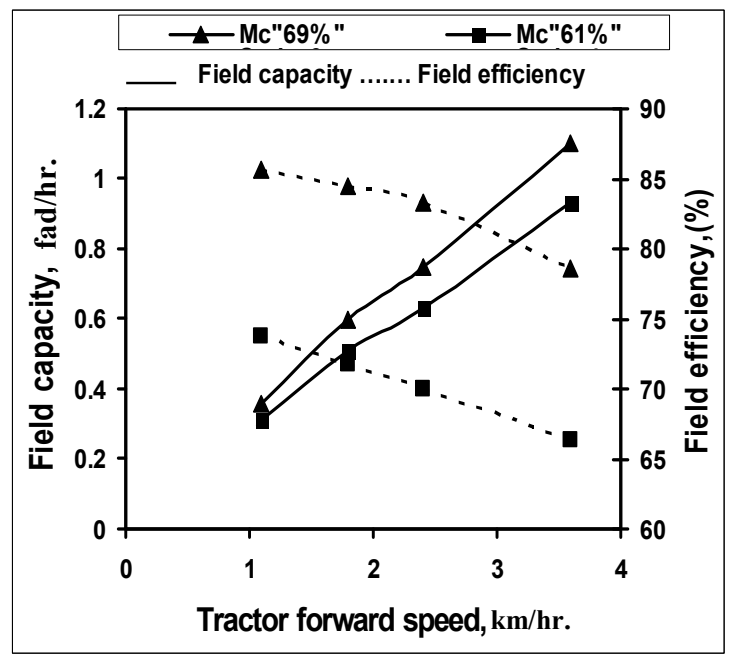

Knife inclination angle $\left(0^{0}\right)$

Fig. 3. Effect of some operating parameters on field capacity and field efficiency

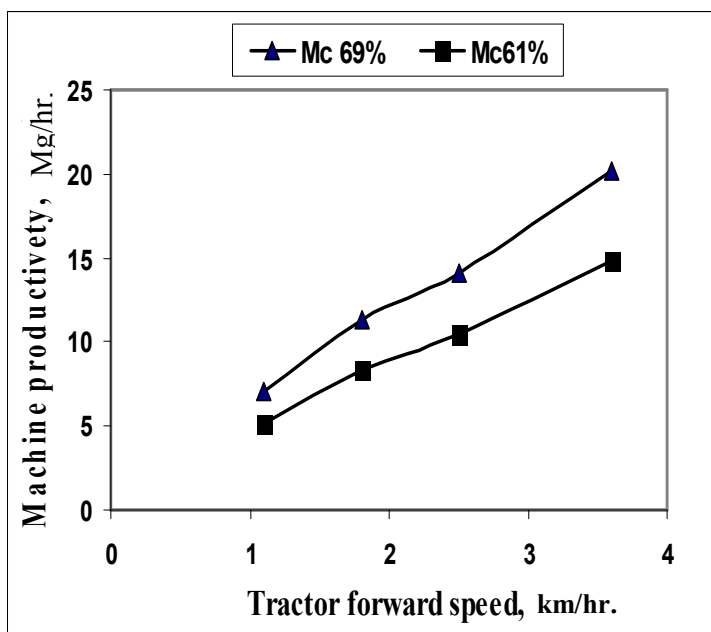

Knife inclination angle $\left(30^{\circ}\right)$

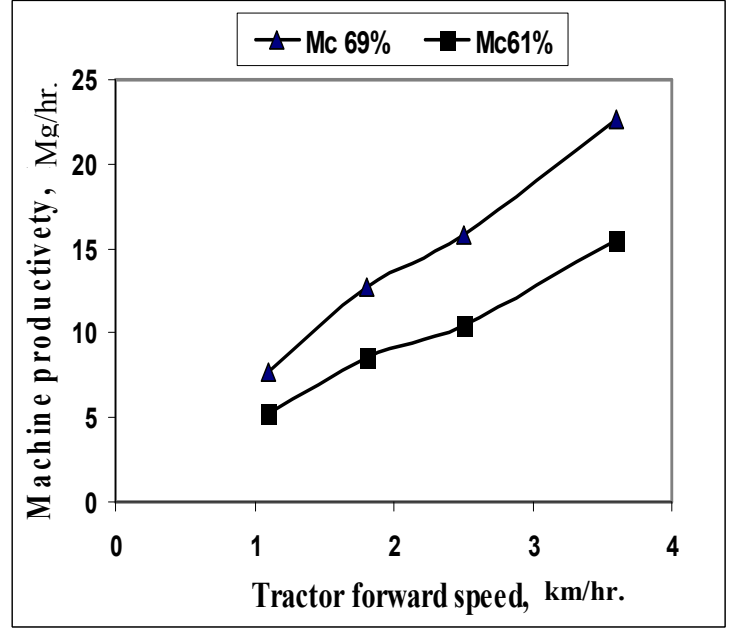

Knife inclination angle $\left(0^{0}\right)$

Fig. 4. Effect of some operating parameters on machine productivity

5.2 to 15.5 and from 7.7 to $22.7 \mathrm{Mg} / \mathrm{hr}$., under corn moisture contents of 61 and $69 \%$, respectively. While increasing forward speed from 1.1 to $3.6 \mathrm{~km} / \mathrm{hr}$, at $30^{\circ}$ knife inclination angle, increased machine productivity values from 5.1 to 14.9 and from 7.1 to $20.2 \mathrm{Mg} / \mathrm{hr}$., under the same previous conditions.

It was noticed that the highest machine productivity of $22.7 \mathrm{Mg} / \mathrm{hr}$., was obtained at forward speed of $3.6 \mathrm{~km} / \mathrm{hr}$., $0^{0}$ knife inclination angle and corn moisture content of $69 \%$. Meanwhile the lowest value of machine productivity of $5.1 \mathrm{Mg} / \mathrm{hr}$., was obtained at forward speed of $1.1 \mathrm{~km} / \mathrm{hr}$., $30^{\circ} \mathrm{knife}$ inclination angle and silage moisture content of $61 \%$.

The major reason for the increment in machine productivity by increasing forward speed is due to the increase in machine filed capacity.

Effect of Some Operating Parameters on Harvesting Losses and Harvesting Efficiency

Representative values of harvesting losses and harvesting efficiency verses forward speed are given under two knife inclination angles and 
two corn moisture contents through various knife velocities in Figs. 5, 6, 7 and 8.

Relating to knife velocity of $950 \mathrm{rpm}$, results showed that increasing forward speed from 1.1 to $3.6 \mathrm{~km} / \mathrm{hr}$., increased harvesting losses values from 0.68 to 1.0 and from 0.9 to $1.3 \mathrm{Mg} / \mathrm{hr}$., under corn moisture contents of 61 and $69 \%$, respectively at $0^{0}$ knife inclination angle. While increasing forward speed from 1.1 to $3.6 \mathrm{~km} / \mathrm{hr}$, increased harvesting losses values from 0.65 to 0.95 and from 0.85 to $1.2 \mathrm{Mg} / \mathrm{hr}$, at $30^{\circ} \mathrm{knife}$ inclination angle, under the same previous conditions. On the other hand, increasing forward speed from 1.1 to $3.6 \mathrm{~km} / \mathrm{hr}$., at knife inclination angle $0^{0}$, leads to decrease harvesting efficiency values from 95.9 to 93.3 and from 95.6 to $93.6 \%$, under silage moisture contents of 61 and $69 \%$, respectively. While increasing forward speed from 1.1 to $3.6 \mathrm{~km} / \mathrm{hr}$., at $30^{0}$ knife inclination angle, leads to decrease harvesting efficiency values from 96.2 to 94.2 and from 96.1 to $94.2 \%$, under the same previous conditions.

Referring to knife velocity of $1050 \mathrm{rpm}$, results also showed that increasing forward speed from 1.1 to $3.6 \mathrm{Km} / \mathrm{hr}$., increased harvesting losses values from 0.62 to 0.95 and from 0.88 to $1.2 \mathrm{Mg} / \mathrm{hr}$., under silage moisture contents of 61 and $69 \%$, respectively at $0^{0}$ knife inclination angle. While increasing forward speed from 1.1 to $3.6 \mathrm{~km} / \mathrm{hr}$, increased harvesting losses values from 0.64 to 0.92 and from 0.83 to $1.15 \mathrm{Mg} / \mathrm{hr}$., at $30^{\circ} \mathrm{knife}$ inclination angle, under the same previous conditions. On the other hand, increasing forward speed from 1.1 to $3.6 \mathrm{~km} / \mathrm{hr}$., at knife inclination angle of $0^{0}$, leads to decrease harvesting efficiency values from 96.2 to 94.2 and from 95.9 to $94.2 \%$ under silage moisture contents of 61 and $69 \%$, respectively. While increasing forward speed from 1.1 to $3.6 \mathrm{~km} / \mathrm{hr}$., at $30^{\circ} \mathrm{knife}$ inclination angle, leads to decrease harvesting efficiency values from 96.3 to 94.4 and from 96.2 to $94.5 \%$, under the same previous conditions.

Considering knife velocity of $1250 \mathrm{rpm}$, results also showed that increasing forward speed from 1.1 to $3.6 \mathrm{Km} / \mathrm{hr}$., increased harvesting losses values from 0.58 to 0.94 and from 0.85 to $1.2 \mathrm{Mg} / \mathrm{hr}$., under silage moisture contents of 61 and $69 \%$, respectively at $0^{\circ}$ knife inclination angle. While increasing forward speed from 1.1 to $3.6 \mathrm{~km} / \mathrm{hr}$., increased harvesting losses values from 0.63 to 0.93 and from 0.81 to $1.1 \mathrm{Mg} / \mathrm{hr}$., at $30^{\circ}$ knife inclination angle, under the same previous conditions. On the other hand, increasing forward speed from 1.1 to $3.6 \mathrm{~km} / \mathrm{hr}$., at knife inclination angle of $0^{0}$, leads to decrease harvesting efficiency values from 96.5 to 94.3 and from 96 to $94.2 \%$ under corn moisture contents of 61 and $69 \%$, respectively. While increasing forward speed from 1.1 to $3.6 \mathrm{~km} / \mathrm{hr}$, at $30^{\circ} \mathrm{knife}$ inclination angle, leads to decrease harvesting efficiency values from 96.6 to 94.4 and from 96.3 to $94.7 \%$, under the same previous conditions.

As to knife velocity of $1350 \mathrm{rpm}$, results also showed that increasing forward speed from 1.1 to $3.6 \mathrm{~km} / \mathrm{hr}$., increased harvesting losses values from 0.55 to 0.93 and from 0.83 to $1.15 \mathrm{Mg} / \mathrm{hr}$., under corn moisture contents of 61 and $69 \%$, respectively at $0^{\circ} \mathrm{knife}$ inclination angle. While increasing forward speed from 1.1 to $3.6 \mathrm{~km} / \mathrm{hr}$., increased harvesting losses values from 0.61 to 0.92 and from 0.8 to $1 \mathrm{Mg} / \mathrm{hr}$., at $30^{\circ} \mathrm{knife}$ inclination angle, under the same previous conditions. On the other hand, increasing forward speed from 1.1 to $3.6 \mathrm{~km} / \mathrm{hr}$ at knife inclination angle of $0^{0}$, leads to decrease harvesting efficiency values from 96.7 to 94.3 and from 96.1 to $94.4 \%$ under corn moisture contents of 61 and $69 \%$, respectively. While increasing forward speed from 1.1 to 3.6 $\mathrm{Km} / \mathrm{hr}$., at $30^{\circ} \mathrm{knife}$ inclination angle, leads to decrease harvesting efficiency values from 96.4 to 94.4 and from 96.3 to $95.2 \%$, under the same conditions.

From this point of view, it was noticed that the highest harvesting losses of $1.3 \mathrm{Mg} / \mathrm{hr}$., was obtained at forward speed of $3.6 \mathrm{~km} / \mathrm{hr}$., knife velocity of $950 \mathrm{rpm}, 0^{0}$ knife inclination angle and silage moisture content of $69 \%$. Meanwhile the lowest value of cutting losses of $0.61 \mathrm{Mg} / \mathrm{hr}$., was obtained at forward speed of $1.1 \mathrm{~km} / \mathrm{hr}$., knife velocity of $1350 \mathrm{rpm}, 30^{\circ}$ knife inclination angle and silage moisture content of $61 \%$. At the same time the highest value of harvesting efficiency of $96.4 \%$, was obtained at forward speed of $1.1 \mathrm{~km} / \mathrm{hr}$., knife velocity of $1350 \mathrm{rpm}$, $30^{\circ}$ knife inclination angle and corn moisture content of $61 \%$. Meanwhile the lowest value of harvesting efficiency of $93.6 \%$ was obtained at forward speed of $3.6 \mathrm{~km} / \mathrm{hr}$., knife velocity of $950 \mathrm{rpm}, 0^{0}$ knife inclination angle and corn moisture content of $69 \%$. 


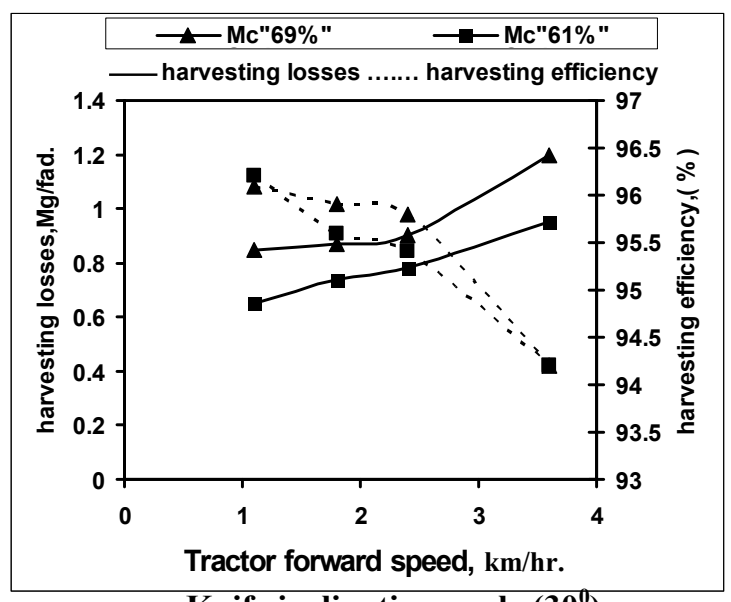

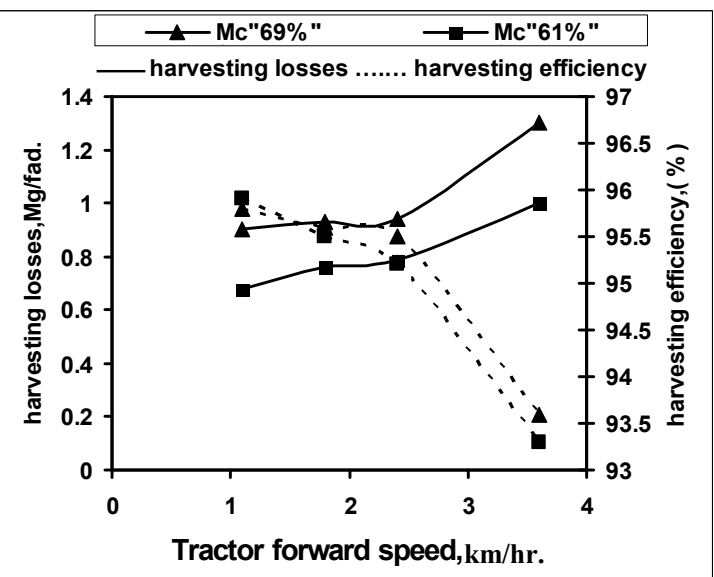

Knife inclination angle $\left(0^{0}\right)$

Fig. 5. Effect of some operating parameters on harvesting losses and harvesting efficiency under knife velocity of $950 \mathrm{rpm}$

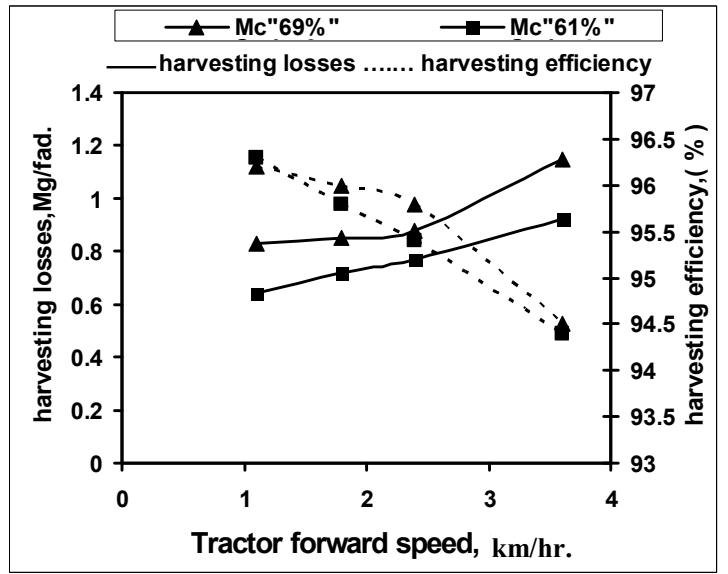

Knife inclination angle $\left(30^{0}\right)$

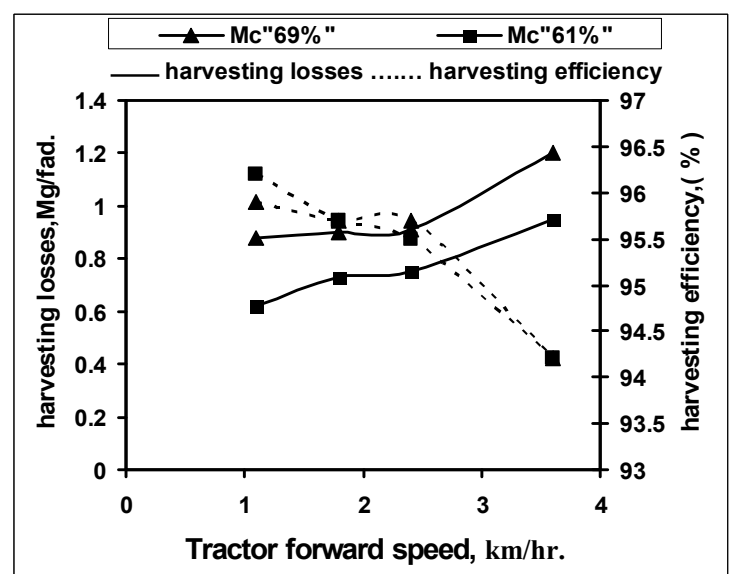

Knife inclination angle $\left(0^{0}\right)$

Fig. 6. Effect of some operating parameters on harvesting losses and harvesting efficiency under knife velocity of $1050 \mathrm{rpm}$

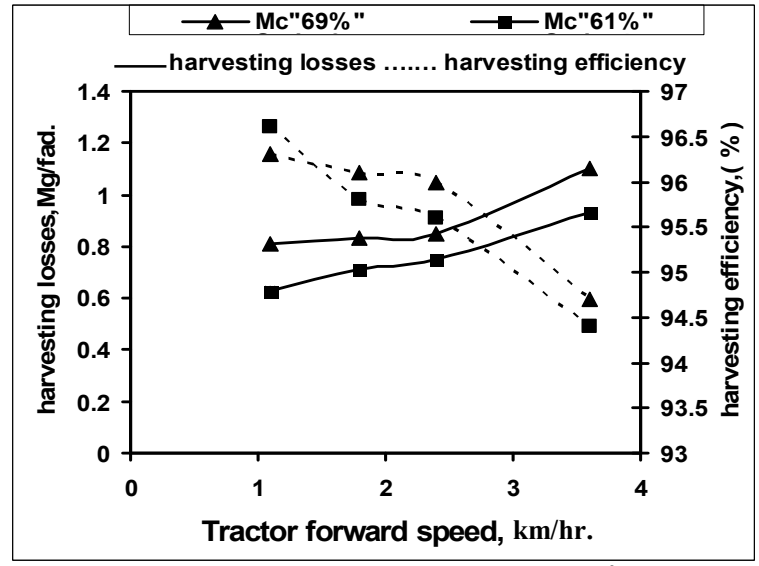

Knife inclination angle $\left(30^{0}\right)$

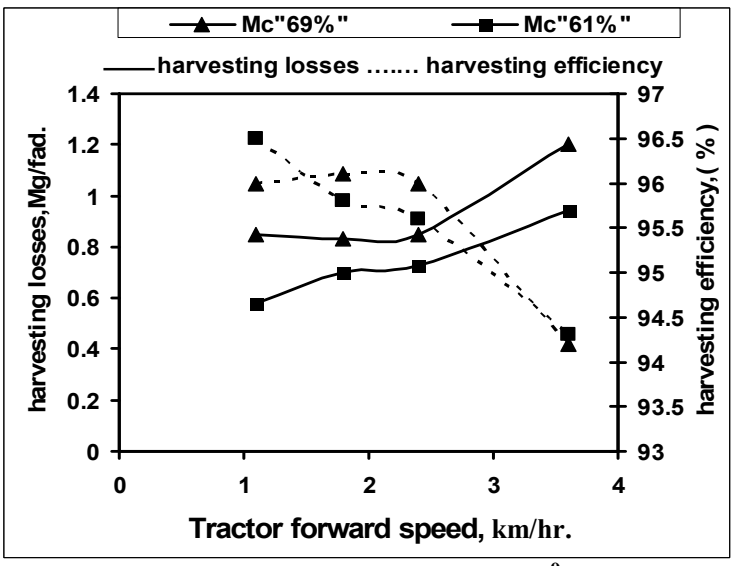

Knife inclination angle $\left(0^{0}\right)$

Fig. 7. Effect of some operating parameters on harvesting losses and harvesting efficiency under knife velocity of $1250 \mathrm{rpm}$ 


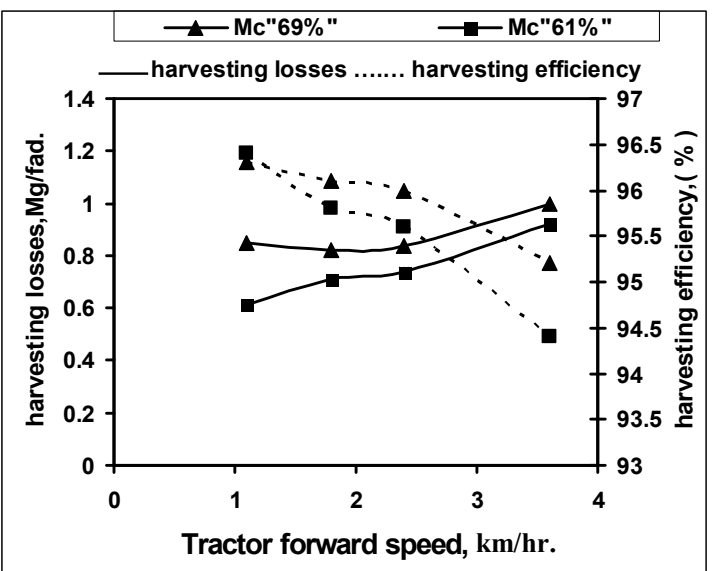

Knife inclination angle $\left(30^{0}\right)$

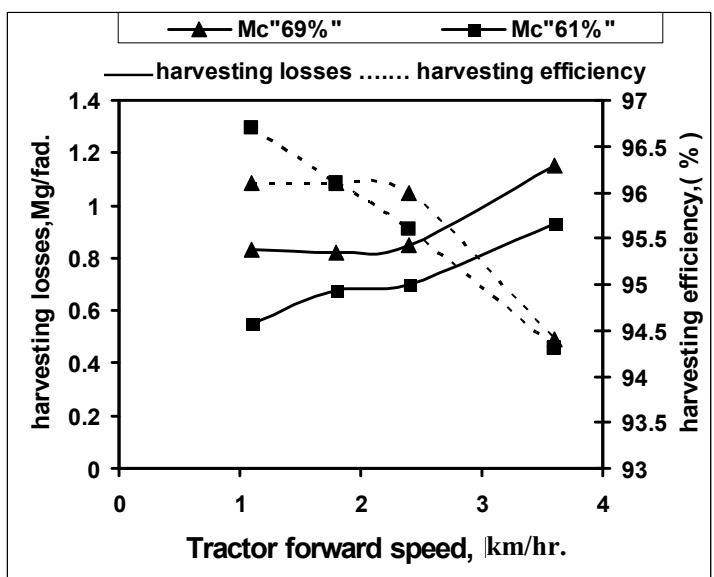

Knife inclination angle $\left(0^{0}\right)$

Fig. 8. Effect of some operating parameters on harvesting losses and harvesting efficiency under knife velocity of 1350 rpm

The increase in harvesting losses at high forward speeds and low knife velocities is attributed to the high vibration of the machine, resulting in high cutting height added to that a great number of plants were left without cutting (especially under low knife velocities) due to bending of plants under the cutting knife, that tends to increase cutting losses.

\section{Effect of Some Operating Parameters on Fuel Consumption}

The effects of forward speed as well as knife inclination angle and silage moisture content on values of fuel consumed per hour and values of fuel consumption per faddan are shown in Fig. 9. The obtained results showed a remarkable rise in fuel consumed per hour with a consequent sharp drop in fuel consumption per faddan as the forwarded speed increased.

Results showed that increasing forward speed from 1.1 to $3.6 \mathrm{~km} / \mathrm{hr}$., at $0^{0}$ knife inclination angle, increased fuel consumed values per hour from 3.69 to 6.37 and from 2.39 to $3.81 / \mathrm{hr}$., under corn moisture contents of 61 and $69 \%$, respectively. While increasing forward speed from 1.1 to $3.6 \mathrm{~km} / \mathrm{hr}$., at $30^{\circ} \mathrm{knife}$ inclination angle, increased fuel consumed values per hour from 3.8 to 5.74 and from 4 to $6.7 \mathrm{l} / \mathrm{hr}$., under the same previous conditions.

On the other hand, increasing forward speed from 1.1 to $3.6 \mathrm{~km} / \mathrm{hr}$., at $0^{0} \mathrm{knife}$ inclination angle, leads to decrease fuel consumption per faddan values from 11.81 to 6.5 and from 6.69 to $3.04 \mathrm{l} /$ fad., under corn moisture contents of 61 and $69 \%$ respectively. While increasing forward speed from 1.1 to $3.6 \mathrm{~km} / \mathrm{hr}$., at $30^{\circ} \mathrm{knife}$ inclination angle, leads to decrease fuel consumption per faddan values from 13.2 to 7.44 and from 11.51 to $5.74 \mathrm{l} /$ fad., under the same previous conditions.

From this point of view, it was noticed that the highest fuel consumed values per hour of 6.7 $1 / \mathrm{hr}$., was obtained at forward speed of 3.6 $\mathrm{km} / \mathrm{hr}$., $30^{\circ}$ knife inclination angle and corn moisture content of $61 \%$. Meanwhile the lowest fuel consumed values per hour of $2.39 \mathrm{l} / \mathrm{hr}$., was obtained at forward speed of $1.1 \mathrm{~km} / \mathrm{hr}$., $0^{\circ} \mathrm{knife}$ inclination angle and corn moisture content of $69 \%$. At the same time, the highest value of fuel consumption per faddan of $13.2 \mathrm{l} / \mathrm{fad}$., was noticed at forward speed of $1.1 \mathrm{~km} / \mathrm{hr}$., $30^{\circ} \mathrm{knife}$ inclination angle and corn moisture content of $61 \%$. Meanwhile the lowest value of fuel consumption per faddan of $3.04 \mathrm{l} / \mathrm{fad}$ was noticed at forward speed of $3.6 \mathrm{~km} / \mathrm{hr}, 0^{0} \mathrm{knife}$ inclination angle and corn moisture content of $69 \%$. The major reason for decreasing fuel consumption per faddan by increasing machine forward speed is due to the increase in actual field capacity.

\section{Effect of Some Operating Parameters on Required Power and Energy Requirements}

The effects of forward speed as well as knife inclination angle and silage moisture content on 


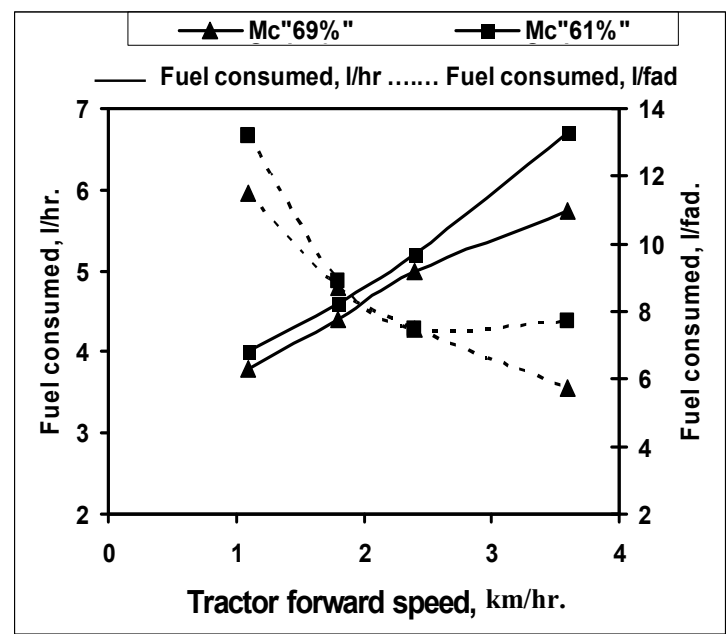

Knife inclination angle $\left(30^{\circ}\right)$

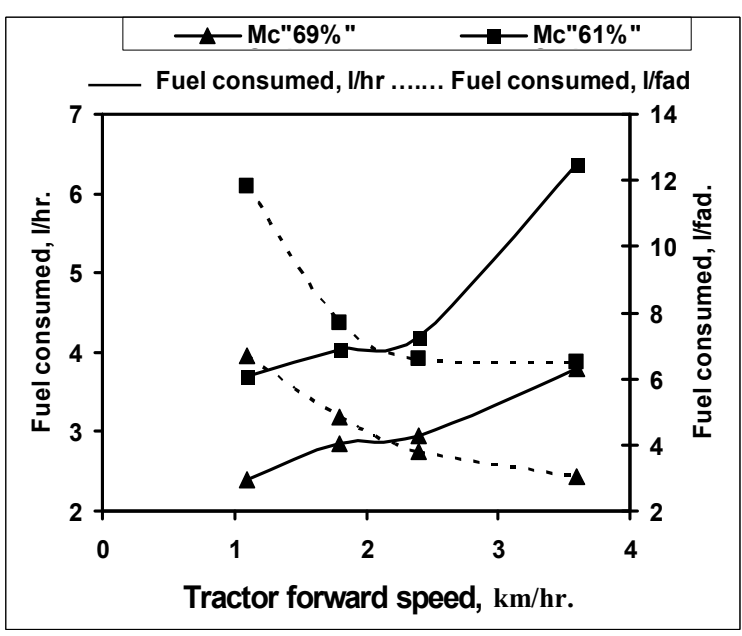

Knife inclination angle $\left(0^{0}\right)$

Fig. 9. Effect of some operating parameters on fuel consumption under constant knife velocity of $1250 \mathrm{rpm}$.

values of required power and energy requirement are shown in Fig. 10. The obtained results show a remarkable rise in required power with a consequent sharp drop in energy requirements as the forwarded speed increased.

Results showed that increasing forward speed from 1.1 to $3.6 \mathrm{~km} / \mathrm{hr}$, at $0^{0} \mathrm{knife}$ inclination angle, increased required power values from 11.7 to 20.1 and from 7.6 to $12 \mathrm{~kW}$ under corn moisture contents of 61 and $69 \%$, respectively. While increasing forward speed from 1.1 to $3.6 \mathrm{~km} / \mathrm{hr}$, at $30^{\circ} \mathrm{knife}$ inclination angle, increased required power values from 12.6 to 21.2 and from 12 to $18.1 \mathrm{~kW}$ under the same previous conditions.

On the other hand, increasing forward speed from 1.1 to $3.6 \mathrm{~km} / \mathrm{hr}$., at $0^{0}$ knife inclination angle, leads to decrease energy requirements values from 37.6 to 21.6 and from 21 to 10.9 $\mathrm{kW} . \mathrm{hr}$./fad., under corn moisture contents of 61 and $69 \%$, respectively. While increasing forward speed from 1.1 to $3.6 \mathrm{~km} / \mathrm{hr}$., at $30^{0} \mathrm{knife}$ inclination angle, leads to decrease energy requirements values from 42.1 to 23.5 and from 36.4 to $18.7 \mathrm{~kW} . \mathrm{hr} . / \mathrm{fad}$., under the same previous conditions.

From this point of view, it was noticed that the highest required power value of $21.2 \mathrm{~kW}$ was obtained at forward speed of $3.6 \mathrm{~km} / \mathrm{hr}$., $30^{\circ}$ knife inclination angle and silage moisture content of $61 \%$. Meanwhile the lowest required power value of $7.6 \mathrm{~kW}$ was obtained at forward speed of $1.1 \mathrm{~km} / \mathrm{hr}$., $0^{0}$ knife inclination angle and corn moisture content of $69 \%$.

At the same time the highest value of energy requirements of $42.1 \mathrm{~kW} . \mathrm{hr}$./fad., was noticed at forward speed of $1.1 \mathrm{~km} / \mathrm{hr}$., $30^{\circ} \mathrm{knife}$ inclination angle and corn moisture content of $61 \%$. Meanwhile the lowest value of energy requirements of $10.9 \mathrm{~kW} . \mathrm{hr}$./fad., was noticed at forward speed of $3.6 \mathrm{~km} / \mathrm{hr}$., $0^{0}$ knife inclination angle and corn moisture content of $69 \%$.

The major reason for increasing required power by increasing forward speed is due to the increase in fuel consumption. But the reason of decreasing energy requirements is due to increase actual field capacity.

\section{Effect of Some Operating Parameters on Operational and Criterion Costs}

Representative values of operational cost and criterion cost verses forward speed are given under two knife inclination angles and two silage moisture contents through various knife velocities in Figs. 11, 12, 13 and 14.

Relating to knife velocity of $950 \mathrm{rpm}$, results showed that increasing forward speed from 1.1 to $3.6 \mathrm{~km} / \mathrm{hr}$., decreased operational cost values from 100 to 42.1 and from 77.3 to $28.6 \mathrm{LE} /$ fad., under corn moisture contents of 61 and 
Ali, et al.

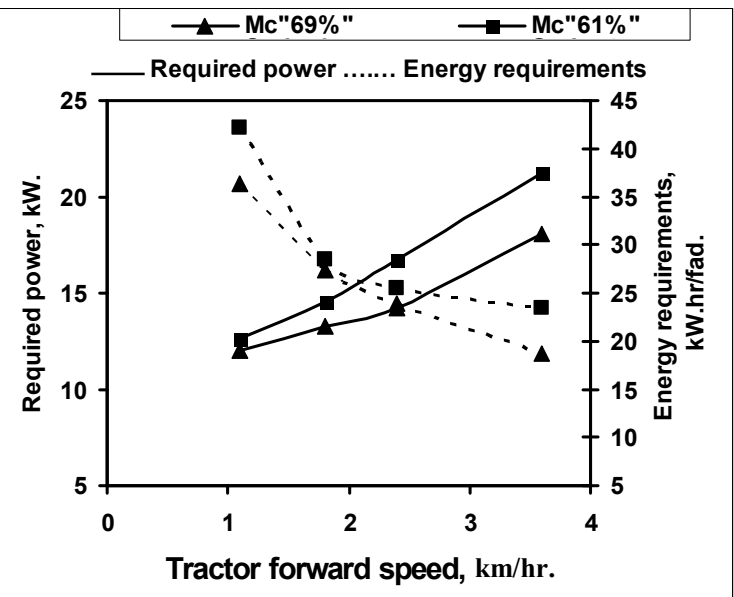

Knife inclination angle (30 $\left.{ }^{\circ}\right)$

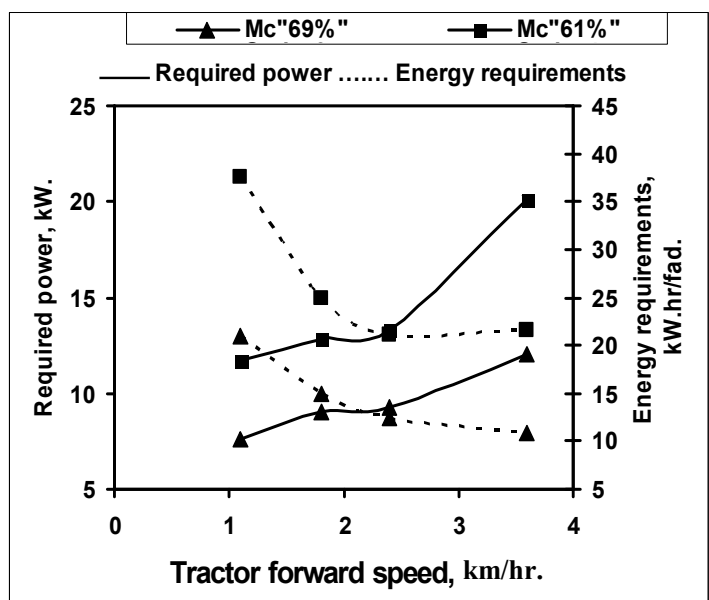

Knife inclination angle $\left(0^{0}\right)$

Fig. 10. Effect of some operating parameters on required power and energy requirements under constant knife velocity of $1250 \mathrm{rpm}$.

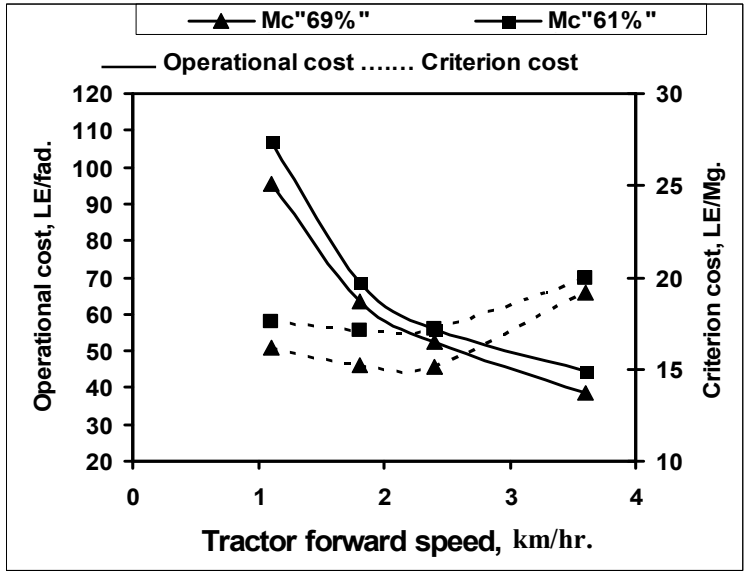

Knife inclination angle $\left(3^{\circ}\right)$

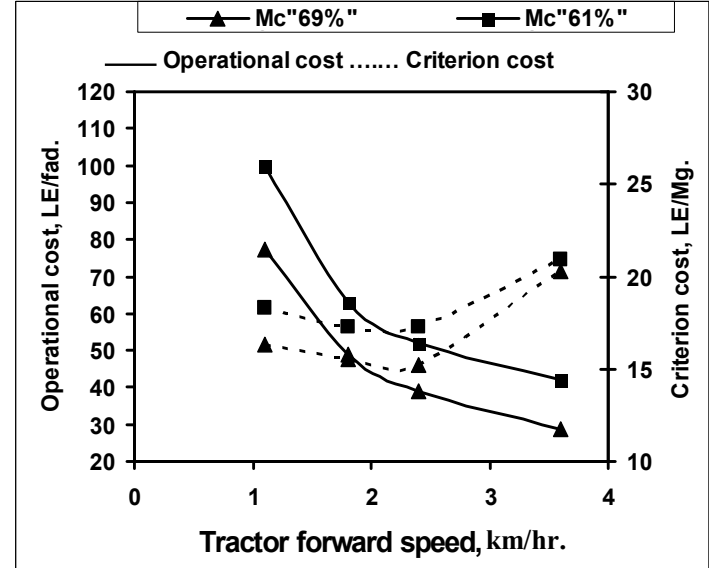

Knife inclination angle $\left(0^{0}\right)$

Fig. 11. Effect of some operating parameters on operational and criterion costs under knife velocity of $950 \mathrm{rpm}$

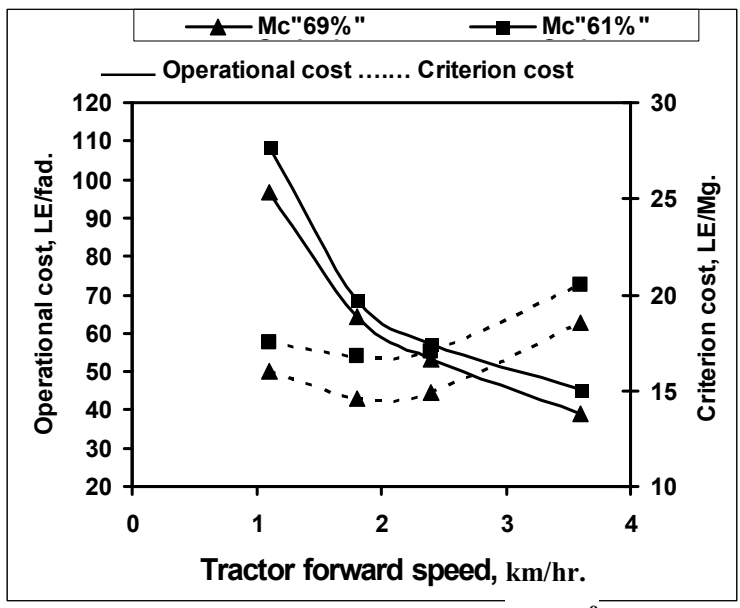

Knife inclination angle $\left(30^{\circ}\right)$

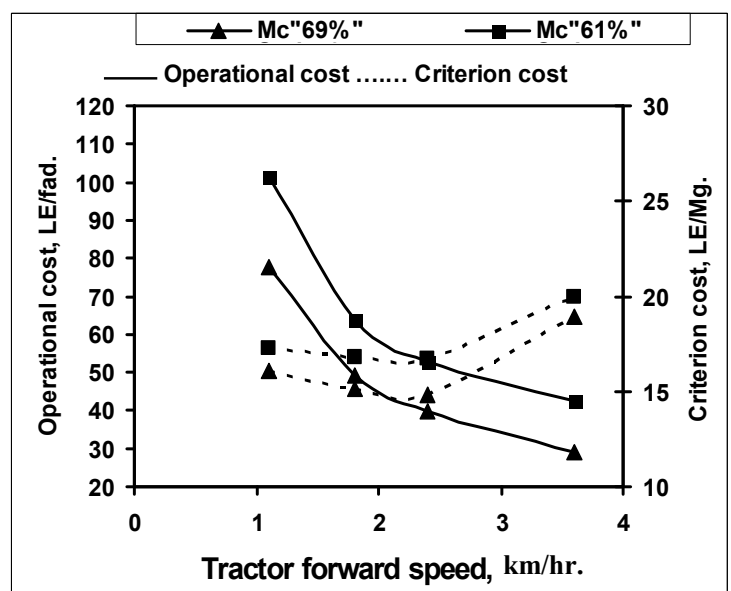

Knife inclination angle $\left(0^{0}\right)$

Fig. 12. Effect of some operating parameters on operational and criterion costs under knife velocity of $1050 \mathrm{rpm}$ 


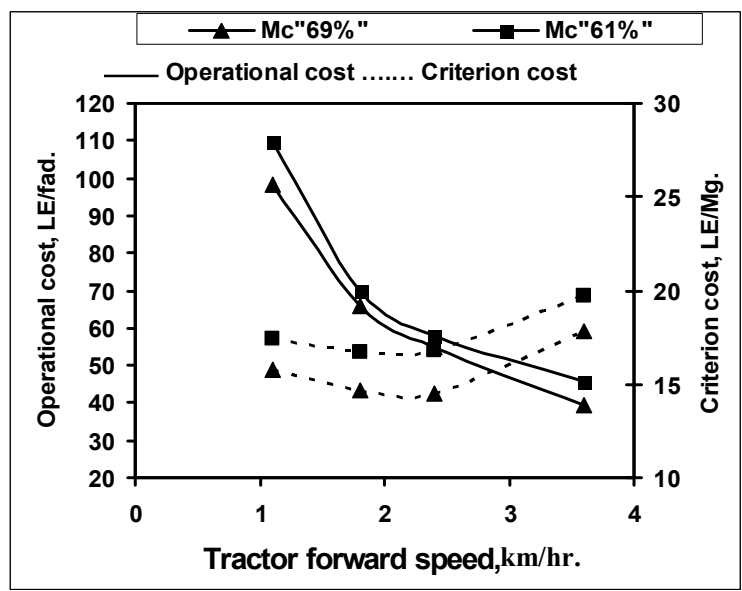

Knife inclination angle $\left(\mathbf{3 0}^{\circ}\right)$

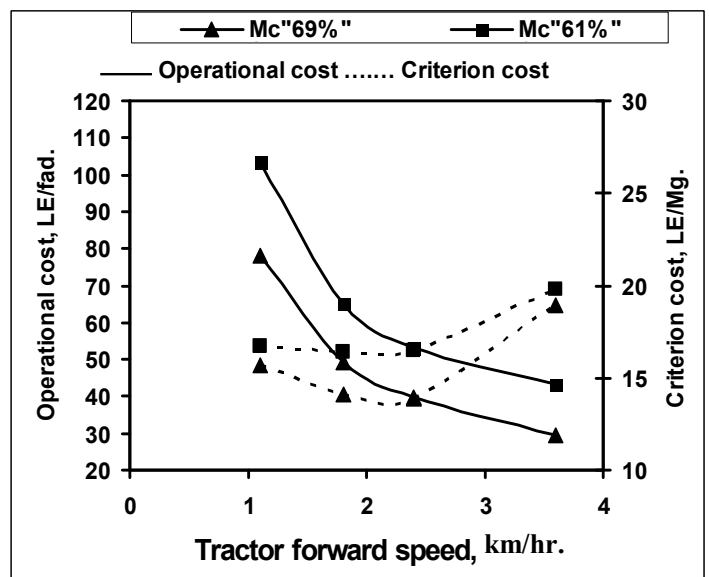

Knife inclination angle $\left(0^{0}\right)$

Fig. 13. Effect of some operating parameters on operational and criterion costs under knife velocity of $1250 \mathrm{rpm}$

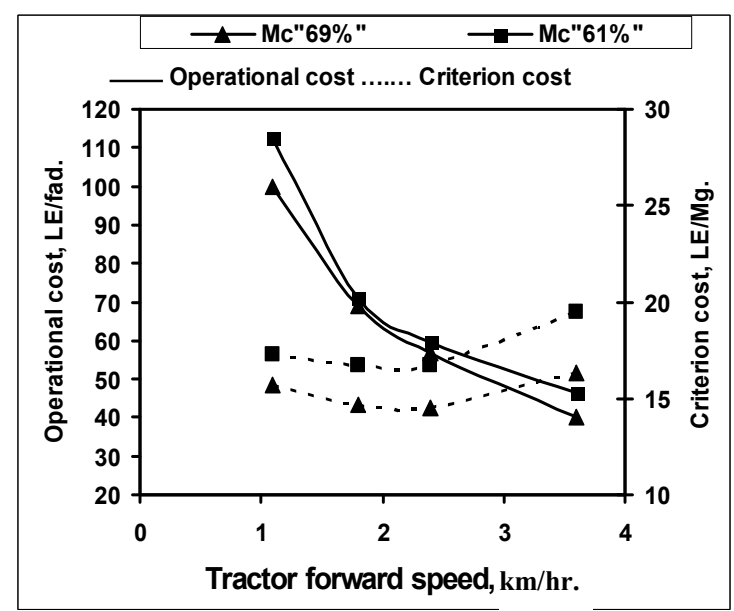

Knife inclination angle $\left(3^{\circ}\right)$

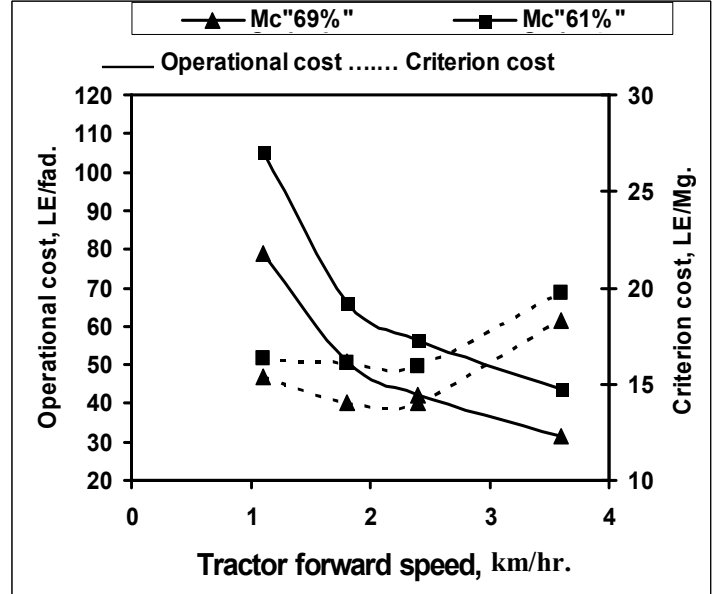

Knife inclination angle $\left(0^{0}\right)$

Fig. 14. Effect of some operating parameters on operational and criterion costs under knife velocity of $1350 \mathrm{rpm}$

$69 \%$, respectively at $0^{0}$ knife inclination angle. While increasing forward speed from 1.1 to 3.6 $\mathrm{km} / \mathrm{hr}$., decreased operational cost values from 106.9 to 44.4 and from 95.3 to $38.4 \mathrm{LE} /$ fad., at $30^{\circ}$ knife inclination angle, under the same previous conditions. On the other hand, increasing forward speed from 1.1 to $2.5 \mathrm{~km} / \mathrm{hr}$., at knife inclination angle of $0^{\circ}$, leads to decrease criterion cost values from 18.3 to 17.3 and from 16.3 to $15.2 \mathrm{LE} / \mathrm{Mg}$. Any further increase in forward speed more than 2.5 up to $3.6 \mathrm{~km} / \mathrm{hr}$., criterion cost values increased to 20.9 and 20.3 $\mathrm{LE} / \mathrm{Mg}$ under corn moisture contents of 61 and $69 \%$, respectively. While increasing forward speed from 1.1 to $2.5 \mathrm{~km} / \mathrm{hr}$., at knife inclination angle of $30^{\circ}$, leads to decrease criterion cost values from 17.6 to 17.2 and from 16.2 to 15.1 $\mathrm{LE} / \mathrm{Mg}$, after then criterion cost values increased to 20 and to $19.2 \mathrm{LE} / \mathrm{Mg}$ by increasing forward speed to $3.6 \mathrm{~km} / \mathrm{hr}$., under the same previous conditions.

Referring to knife velocity of $1050 \mathrm{rpm}$, results showed that increasing forward speed from 1.1 to $3.6 \mathrm{~km} / \mathrm{hr}$., decreased operational cost values from 101.6 to 42.1 and from 77.9 to 29.2 LE/fad., under corn moisture contents of 61 and $69 \%$, respectively at $0^{\circ}$ knife inclination angle. While increasing forward speed from 1.1 to $3.6 \mathrm{~km} / \mathrm{hr}$, decreased operational cost values 
from 108.5 to 45.1 and from 96.7 to 38.9 $\mathrm{LE} /$ fad., at $30^{\circ} \mathrm{knife}$ inclination angle, under the same previous conditions. On the other hand, increasing forward speed from 1.1 to $2.5 \mathrm{~km} / \mathrm{hr}$., at knife inclination angle of $0^{\circ}$, leads to decrease criterion cost values from 17.3 to 16.7 and from 16.1 to $14.8 \mathrm{LE} / \mathrm{Mg}$. Any further increase in forward speed more than 2.5 up to $3.6 \mathrm{~km} / \mathrm{hr}$., criterion cost values increased to 20 and 18.9 $\mathrm{LE} / \mathrm{Mg}$ under corn moisture contents of 61 and $69 \%$, respectively.

While increasing forward speed from 1.1 to $2.5 \mathrm{~km} / \mathrm{hr}$., at knife inclination angle $30^{\circ}$, leads to decrease criterion cost values from 17.5 to 17 and from 16 to $14.9 \mathrm{LE} / \mathrm{Mg}$, after then criterion cost increased to 20.5 and $18.5 \mathrm{LE} / \mathrm{Mg}$ at forward speed of $3.6 \mathrm{~km} / \mathrm{hr}$., under the same previous conditions.

Considering to knife velocity of $1250 \mathrm{rpm}$, results showed that increasing forward speed from 1.1 to $3.6 \mathrm{Km} / \mathrm{hr}$., decreased operational cost values from 103.4 to 43.2 and from 78 to 29.2 LE/fad., under corn moisture contents of 61 and $69 \%$, respectively at $0^{0}$ knife inclination angle. While increasing forward speed from 1.1 to $3.6 \mathrm{~km} / \mathrm{hr}$., decreased operational cost values from 109.9 to 45.8 and from 98.1 to 39.4 $\mathrm{LE} /$ fad., at $30^{\circ} \mathrm{knife}$ inclination angle, under the same previous conditions. On the other hand, increasing forward speed from 1.1 to $2.5 \mathrm{~km} / \mathrm{hr}$ at knife inclination angle of $0^{0}$, leads to decrease criterion cost values from 16.7 to 16.5 and from 15.7 to $13.9 \mathrm{LE} / \mathrm{Mg}$, after then criterion cost increased to 19.8 and $18.9 \mathrm{LE} / \mathrm{Mg}$ by increasing forward speed to $3.6 \mathrm{~km} / \mathrm{hr}$., under corn moisture contents of 61 and $69 \%$, respectively. While increasing forward speed from 1.1 to 2.5 $\mathrm{km} / \mathrm{hr}$., at knife inclination angle of $30^{\circ}$, leads to decrease criterion cost values from 17.4 to 16.8 and from 15.8 to $14.5 \mathrm{LE} / \mathrm{Mg}$, after then criterion cost increased to 19.7 and $17.8 \mathrm{LE} / \mathrm{Mg}$ by increasing forward speed to $3.6 \mathrm{~km} / \mathrm{hr}$., under the same previous conditions.

As to knife velocity of $1350 \mathrm{rpm}$, results showed that increasing forward speed from 1.1 to $3.6 \mathrm{~km} / \mathrm{hr}$., decreased operational cost values from 105.3 to 43.9 and from 79 to $31.4 \mathrm{LE} /$ fad., under corn moisture contents of 61 and $69 \%$, respectively at $0^{0}$ knife inclination angle. While increasing forward speed from 1.1 to $3.6 \mathrm{~km} / \mathrm{hr}$, decreased operational cost values from 112.5 to 46.4 and from 99.9 to $40 \mathrm{LE} /$ fad., at $30^{\circ} \mathrm{knife}$ inclination angle, under the same previous conditions. On the other hand, increasing forward speed from 1.1 to $2.5 \mathrm{~km} / \mathrm{hr}$., at knife inclination angle of $0^{0}$, leads to decrease criterion cost values from 16.3 to 15.9 and from 15.4 to $14 \mathrm{LE} / \mathrm{Mg}$, after then criterion cost increased to 19.7 and $18.3 \mathrm{LE} / \mathrm{Mg}$ by increasing forward speed to $3.6 \mathrm{~km} / \mathrm{hr}$., under corn moisture contents of 61 and $69 \%$, respectively. While increasing forward speed from 1.1 to 2.5 $\mathrm{km} / \mathrm{hr}$., at knife inclination angle of $30^{\circ}$, leads to decrease criterion cost values from 17.3 to 16.7 and from 15.7 to $14.5 \mathrm{LE} / \mathrm{Mg}$, after then criterion cost increased to 19.5 and to 16.3 $\mathrm{LE} / \mathrm{Mg}$ by increasing forward speed to 3.6 $\mathrm{km} / \mathrm{hr}$., under the same previous conditions.

From this point of view, it was noticed that the highest operational cost value of 112.5 LE/fad., was obtained at forward speed of 1.1 $\mathrm{km} / \mathrm{hr}$., knife velocity of $1350 \mathrm{rpm}, 30^{\circ} \mathrm{knife}$ inclination angle and corn moisture content of $61 \%$. Meanwhile the lowest value of operational cost of $28.6 \mathrm{LE} / \mathrm{fad}$., was obtained at forward speed of $3.6 \mathrm{~km} / \mathrm{hr}$., knife velocity of $950 \mathrm{rpm}$, $0^{0}$ knife inclination angle and corn moisture content of $69 \%$.

At the same time, the highest value of criterion cost of $20.9 \mathrm{LE} / \mathrm{Mg}$ was obtained at forward speed of $3.6 \mathrm{~km} / \mathrm{hr}$., knife velocity of $950 \mathrm{rpm}, 30^{\circ}$ knife inclination angle and corn moisture content of $61 \%$. Meanwhile the lowest value of criterion cost of $13.9 \mathrm{LE} / \mathrm{Mg}$ was obtained at forward speed of $2.5 \mathrm{~km} / \mathrm{hr}$, knife velocity of $1250 \mathrm{rpm}, 0^{0}$ knife inclination angle and corn moisture content of $69 \%$.

The major reason for decreasing operational cost by increasing forward speed and decreasing knife velocity is attributed to the increase in field capacity. While the major reason for increasing criterion cost by increasing forward speed more than 2.5 up to $3.6 \mathrm{~km} / \mathrm{hr}$ is due to increasing harvesting losses.

\section{Conclusion}

The experimental results revealed that harvesting losses as well as criterion costs were 
minimum while harvesting efficiency was maximum under the following conditions:

- Operate the machine at a forward speed of 2.5 $\mathrm{km} / \mathrm{hr}$.

- Operate the harvesting device at a knife velocity of $1250 \mathrm{rpm}$.

- Adjust knife inclination angle at zero degree.

- Harvest silage at a stalk moisture content of about 69\%(wb).

\section{REFERENCES}

Bentini, M., M. Zucchelli and P. Pasini (2008). Harvesting biomass sorghum based on its destination. Inf. Agrario., 64 (12): 67-70.

CFIEI (2002). Canadian Farm and Industrial Equipment Institute. Industry Outlook.

Chattopadhyay and Pandey (1999). Mechanical properties of sorghum stalk in relation to quasi-static deformation. J. Agric. Eng. Res., 73: 199-206.
Diao, P.O., Z.D. Lin, Y.C. Yun and L. Pan (2011). Development of vertical type combine harvester for corn and stalk. Int. Agric. Eng. J., 20: 1, 58-61.

GAIN Report (2016) USD A Foreign Agriculture Service, Global Agricultural Information Network, Egypt Grain and Feed Annual, Date: 3/10/2016

Hunt, D. (1983). Farm Power and Machinery Mangment. Iowa state U. press Ames, Iowa, USA.

Kepner, R.A., R. Bainer and E.L. Barger (1987). Principals of Farm Machinery, $3^{\text {rd }}$ Ed., AviPub. Co., 315-318

Shinners, K.J., G.C. Boettcher, D.S. Hoffman, J.T. Munk, R.E. Muck and P.J. Weimer (2009). Single-Pass Harvest of Corn Grain and Stover: Performance of Three Harvester Configurations. Transactions of the ASABE, 52 (1): 51-60.

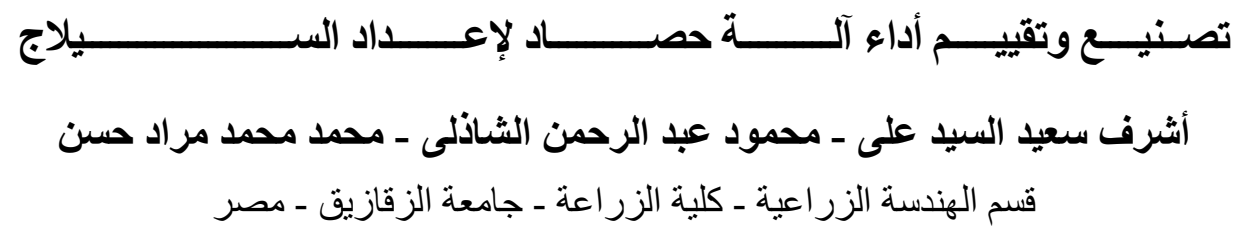

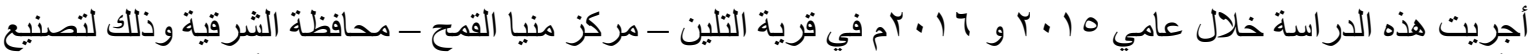

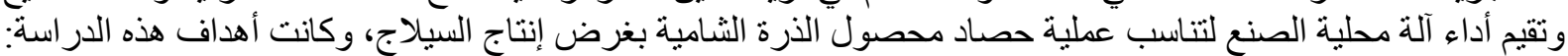

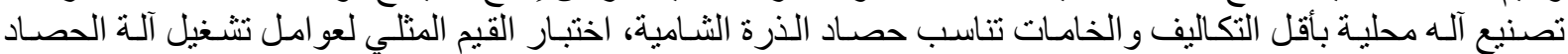

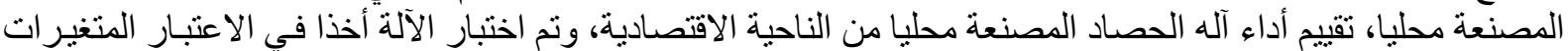

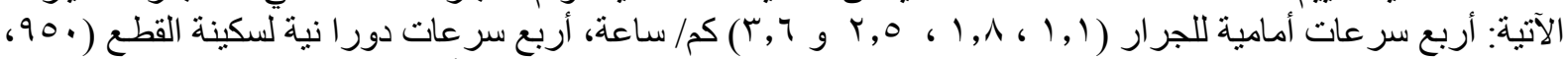

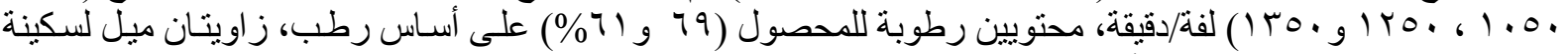

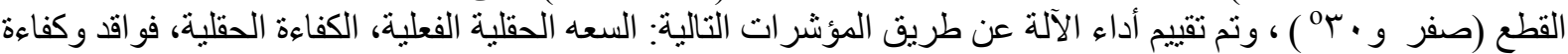

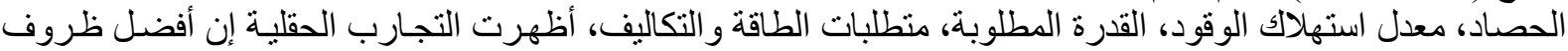

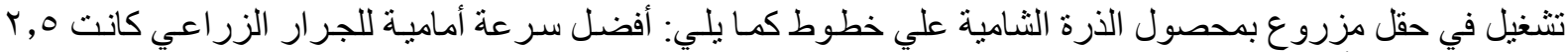

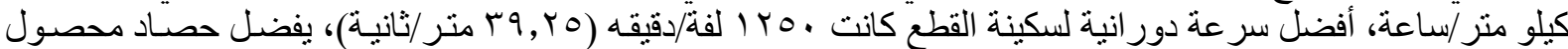
الذرة الثامية عند محتوي رطوبة 79\%، زائة زاية ميل سكينة القطع صفر بالنسبة للمحور الأفقي. 